\title{
Effect of sodium nitrite on the $\alpha$-chlorohydrin-induced lesion of the testis-epididymis complex in the rat
}

\author{
Natwar R. Kalla and B. Singh \\ Department of Biophysics, Panjab University, Chandigarh 160014, India
}

\begin{abstract}
Summary. Administration of vasodilator, sodium nitrite $(20 \mathrm{mg} / \mathrm{kg}$ body weight $), 30$ $\min$ before $\alpha$-chlorohydrin treatment $(90 \mathrm{mg} / \mathrm{kg}$ body weight) prevented the chlorohydrin-induced lesion in rat testis-epididymis complex. However, administration of vasodilator 90 min after $\alpha$-chlorohydrin treatment did not prevent the chlorohydrininduced lesion in the testis-epididymis complex. These observations suggest that the testicular vasculature is involved in drug action.
\end{abstract}

\section{Introduction}

Reports in the current literature indicate that $\alpha$-chlorohydrin, an antifertility agent, has at least two sites of action in the male rat. At low doses the drug induces functional interference of the spermatozoa, causing reversible sterility, while a single high dose produces a characteristic lesion in the caput epididymidis, leading to the occlusion of the epididymal duct and subsequent degeneration of the germinal epithelium and permanent sterility (Kalla, 1976). The involvement of the testicular vasculature (pampiniform plexus complex) in the mode of action of a high dose of $\alpha$-chlorohydrin has been suggested by a number of workers (Ericsson, 1970; Gunn, Gould \& Anderson, 1970; Reijonen, Kormano \& Ericsson, 1975). Ericsson \& Norland (1970) reported that norepinephrine, a vasoconstrictor $(1.5-6.5 \mathrm{mg} / \mathrm{kg}$ body weight), potentiated the effect of $\alpha$ chlorohydrin in the rat $(81 \%$ with lesions compared to $12 \%$ with the same dose $(30 \mathrm{mg} / \mathrm{kg}$ body weight) of $\alpha$-chlorohydrin alone). A vasodilator, therefore, should negate the $\alpha$-chlorohydrininduced lesion and the present investigations were carried out to test this hypothesis.

\section{Materials and Methods}

Sexually mature male albino rats, weighing $170-195 \mathrm{~g}$, were divided into 5 groups (Table 1). All the treatments were by oral intubation. The rats in Group 1 were given a single dose of $90 \mathrm{mg} \alpha$ chlorohydrin $/ \mathrm{kg}$ body weight in $1 \mathrm{ml} 0.9 \%(\mathrm{w} / \mathrm{v})$ sodium chloride. In Group 2, the vasodilator, sodium nitrite (Sigma), was given as a dose of $20 \mathrm{mg} / \mathrm{kg}$ body weight $90 \mathrm{~min}$ after a single oral dose of $90 \mathrm{mg} \alpha$-chlorohydrin $/ \mathrm{kg}$ body weight. In Group 3 the sodium nitrite $(20 \mathrm{mg} / \mathrm{kg}$ body weight) was given $30 \mathrm{~min}$ before the $\alpha$-chlorohydrin administration. The rats in Group 4 were treated with $20 \mathrm{mg}$ sodium nitrite $/ \mathrm{kg}$ body weight alone. Animals in Group 5 served as controls and were given $1 \mathrm{ml} 0.9 \%(\mathrm{w} / \mathrm{v})$ sodium chloride. The doses of sodium nitrite and $\alpha$-chlorohydrin were used according to the methods of Sankaranarayanan (1974) and Ericsson (1970) respectively. The $\alpha$-chlorohydrin (3,chloro-1,2-propanediol) was made available through courtesy of Dr R. J. Ericsson, Gametrics, Sausalito, California.

The rats were killed 6 days after the drug treatment. The animals were weighed before being killed and the testes and epididymides were dissected out, separated, blotted dry and weighed. The tissues were fixed in Bouin's solution and after routine histology and staining with haematoxylin and eosin, sections of the seminiferous tubules and caput epididymidis were 
examined. The diameter and the basement membrane thickness were measured in 20 crosssections of tubules in each testis. The $\alpha$-chlorohydrin-induced lesions in the testis-epididymis complex were identified according to those characterized by Ericsson (1970), i.e. sperm blockage in the efferent ducts, degeneration of the germinal epithelium marked by the presence of multinucleated giant cells in the seminiferous tubules, desquamation of the epithelium of the caput epididymidis and blockage of the lumen by the exfoliated germinal and epithelial cells.

Data from Groups 3-5 were compared with Groups 1 and 2 using Student's $t$ test and the null hypothesis.

\section{Results}

Table 1 summarizes the weight changes in the testis-epididymis complex observed in the 5 groups. In Groups 1 and 2 there was an increase in the diameter of the seminiferous tubules and the thickness of the basement membrane. Typical chlorohydrin-type lesions in the testisepididymis complex were observed in the animals of Groups 1 and 2. However, for the characteristics examined, the animals in Groups 3 and 4 were identical to those in Group 5.

Table 1. Changes (mean \pm s.d.) in the rat testis-epididymis complex after various treatments

\begin{tabular}{|c|c|c|c|c|c|c|c|c|}
\hline \multirow[b]{2}{*}{ Group } & \multirow[b]{2}{*}{ Treatment } & \multirow[b]{2}{*}{$\begin{array}{l}\text { No. of } \\
\text { rats/ } \\
\text { group }\end{array}$} & \multirow[b]{2}{*}{$\begin{array}{l}\text { Body } \\
\text { wt } \\
(\mathrm{g})\end{array}$} & \multirow[b]{2}{*}{$\begin{array}{l}\text { Testes } \\
\text { wt } \\
(\mathrm{g})\end{array}$} & \multirow[b]{2}{*}{$\begin{array}{c}\text { Epididymides } \\
\text { wt } \\
(\mathrm{g})\end{array}$} & \multirow[b]{2}{*}{$\begin{array}{l}\text { Rats with } \\
\text { epididymal } \\
\text { lesions (\%) }\end{array}$} & \multicolumn{2}{|c|}{ Seminiferous tubules } \\
\hline & & & & & & & Diam. $(\mu \mathrm{m})$ & $\begin{array}{c}\text { Basement } \\
\text { membrane } \\
\text { thickness }(\mu \mathrm{m})\end{array}$ \\
\hline 1 & $\alpha$-Chlorohydrin & 18 & $180 \pm 7 \cdot 5$ & $\begin{array}{l}1.48 \\
\pm 0.09\end{array}$ & $\begin{array}{l}0.327 \\
\quad \pm 0.011 \dagger\end{array}$ & $16(89)$ & $303 \pm 14 \dagger$ & $2 \cdot 30 \pm 0 \cdot 60^{*}$ \\
\hline 2 & $\begin{array}{l}\text { Sodium nitrite } \\
90 \text { min after } \\
\alpha \text {-chlorohydrin }\end{array}$ & 12 & $179 \pm 5 \cdot 9$ & $\begin{array}{l}1.46 \\
\pm 0.07\end{array}$ & $\begin{array}{l}0.323 \\
\quad \pm 0.012 \dagger\end{array}$ & $11(91)$ & $299 \pm 11 \dagger$ & $2 \cdot 60 \pm 0.40^{*}$ \\
\hline 3 & $\begin{array}{l}\text { Sodium nitrite } \\
30 \text { min before } \\
\alpha \text {-chlorohydrin }\end{array}$ & 12 & $181 \pm 7 \cdot 6$ & $\begin{array}{l}1.11 \\
\pm 0.08\end{array}$ & $\begin{array}{l}0.305 \\
\quad \pm 0.010\end{array}$ & $1(8 \cdot 5)$ & $250 \pm 13$ & $1.82 \pm 0.41$ \\
\hline 4 & Sodium nitrite & 12 & $178 \pm 6 \cdot 7$ & $\begin{array}{l}1.11 \\
\pm 0.05\end{array}$ & $\begin{array}{l}0.303 \\
\quad \pm 0.011\end{array}$ & $0(0)$ & $246 \pm 11$ & $1.75 \pm 0.32$ \\
\hline 5 & $\begin{array}{l}\text { Saline } \\
\quad \text { (control) }\end{array}$ & 12 & $180 \pm 8 \cdot 0$ & $\begin{array}{l}1 \cdot 10 \\
\pm 0.05\end{array}$ & $\begin{array}{l}0.300 \\
\quad \pm 0.013\end{array}$ & $0(0)$ & $249 \pm 12$ & $1 \cdot 86 \pm 0.40$ \\
\hline
\end{tabular}

$* P<0.05$.

$\dagger P<0.01$.

\section{Discussion}

The present results suggest that the lesion produced in the rat testis-epididymis complex after a single high dose of $\alpha$-chlorohydrin can be negated by prior treatment with a vasodilator such as sodium nitrite. Similarly Bocabella, Salgado \& Alger (1962) have shown that 5hydroxytryptamine-induced lesions in the rat testis-epididymis complex could be negated by administration of the vasodilator, aspersoline 1-hydrazinophthalazime.

Vasodilators act either by depressing the vasoconstrictor centres of ganglia or by a direct action on the blood vessel (Wilson \& Schild, 1955). Nitrites, however, produce no effect on vasomotor centres and have no direct effect on heart muscles (Wilson \& Schild, 1955). Sodium nitrite given orally is rapidly absorbed through the mucous membrane of the mouth and gastrointestinal tract, and the effect is maximal after about 10-20 min, the duration of response being 2 
h. Other volatile nitrites are given by the nasal route and are short lived, lasting only for 20-30 min (Musser \& Shubkagal, 1965). In the present investigations, therefore, oral administration of the sodium nitrite $30 \mathrm{~min}$ before the $\alpha$-chlorohydrin treatment would achieve maximum effectiveness at the time of drug treatment and would maintain the effectiveness for a period long enough to overlap with that when the effect of the $\alpha$-chlorohydrin is becoming apparent. The action of $\alpha$ chlorohydrin is seen microscopically within $2 \mathrm{~h}$; these early changes involve the nucleus, surface and cytoplasm of the cells of the initial segment of the epididymis (Hoffer, Hamilton \& Fawcett, 1973).

Ligation of the local epididymal arterial bed (Masson, Shaver, Hodge \& Maynard, 1951) produces microscopic changes which are identical, i.e. in the time of formation, location, type and final disposition, to those induced by $\alpha$-chlorohydrin (McMillan, 1953, 1956).

The present investigations and those of Ericsson \& Norland (1970) confirm our belief that the lesion produced in the rat testis-epididymis complex after a single high dose of $\alpha$-chlorohydrin is associated with changes in the testicular blood supply.

\section{References}

Bocabella, A.V., Salgado, E.D. \& Alger, E.A. (1962) Testicular function and histology following serotonin administration. Endocrinology 71, 827-837.

Ericsson, R.J. (1970) Male antifertility compounds; U5897 as a rat chemosterilant. $J$. Reprod. Fert. 22, 213-222.

Ericsson, R.J. \& Norland, J.F. (1970) Potentiating responses with norepinephrin to rat chemosterilant alpha-chlorohydrin. Proc. 52nd Annual Endocrine Soc. Meeting, Missouri, Abstr. No. 243.

Gunn, S.A., Gould, T.C. \& Anderson, W.A.D. (1970) Comparative mechanism of action of monochlorohydrin and cadmium induced necrosis of the caput epididymis of the rat. Biol. Reprod. 3, 35-42.

Hoffer, A.P., Hamilton, D.W. \& Fawcett, D.W. (1973) Ultrastructure pathology of the rat epididymis after administration of alpha chlorohydrin (U-5897). I. Effects of a single high dose. Anat. Rec. 175, 203230.

Kalla, N.R. (1976) Chlorohydrins in male fertility regulation. Biblphy Reprod. 28, 261-267.

Masson, K.E., Shaver, S.L., Hodge, H.C. \& Maynard, E.A. (1951) Extensive intratubular edema of the rat testis compatible with spermatogenic function. Anat. Rec. 189, 102-113.

McMillan, E.W. (1953) The effect of interruption of the vasal and inferior epididymal arteries on the cauda epididymidis and testis. Studs Fert. 5, 12-19.

McMillan, E.W. (1956) The immediate effects of occlusion of superior epididymal arteries in the rat as demonstrated by the use of radio-opaque medium. Studs Fert. 8, 67-75.

Musser, R.D. \& Shubkagal, B.L. (1965) Pharmacology and Therapeutics. Macmillan, New York.

Reijonen, K., Kormano, M. \& Ericsson, R.J. (1975) Studies on the rat epididymal blood vessels following alpha-chlorohydrin administration. Biol. Reprod. 12, 483-490.

Sankaranarayanan, A. (1974) Interaction of alpha and beta adrenoreceptor antagonists with observation on its mechanisms. Ph.D. thesis, Post-graduate Institute of Medical Education and Research, Chandigarh.

Wilson, A. \& Schild, H.O. (1955) Clark's Applied Pharmacology, pp. 366-367. McGraw Hill, New York.

Received 18 August 1978 